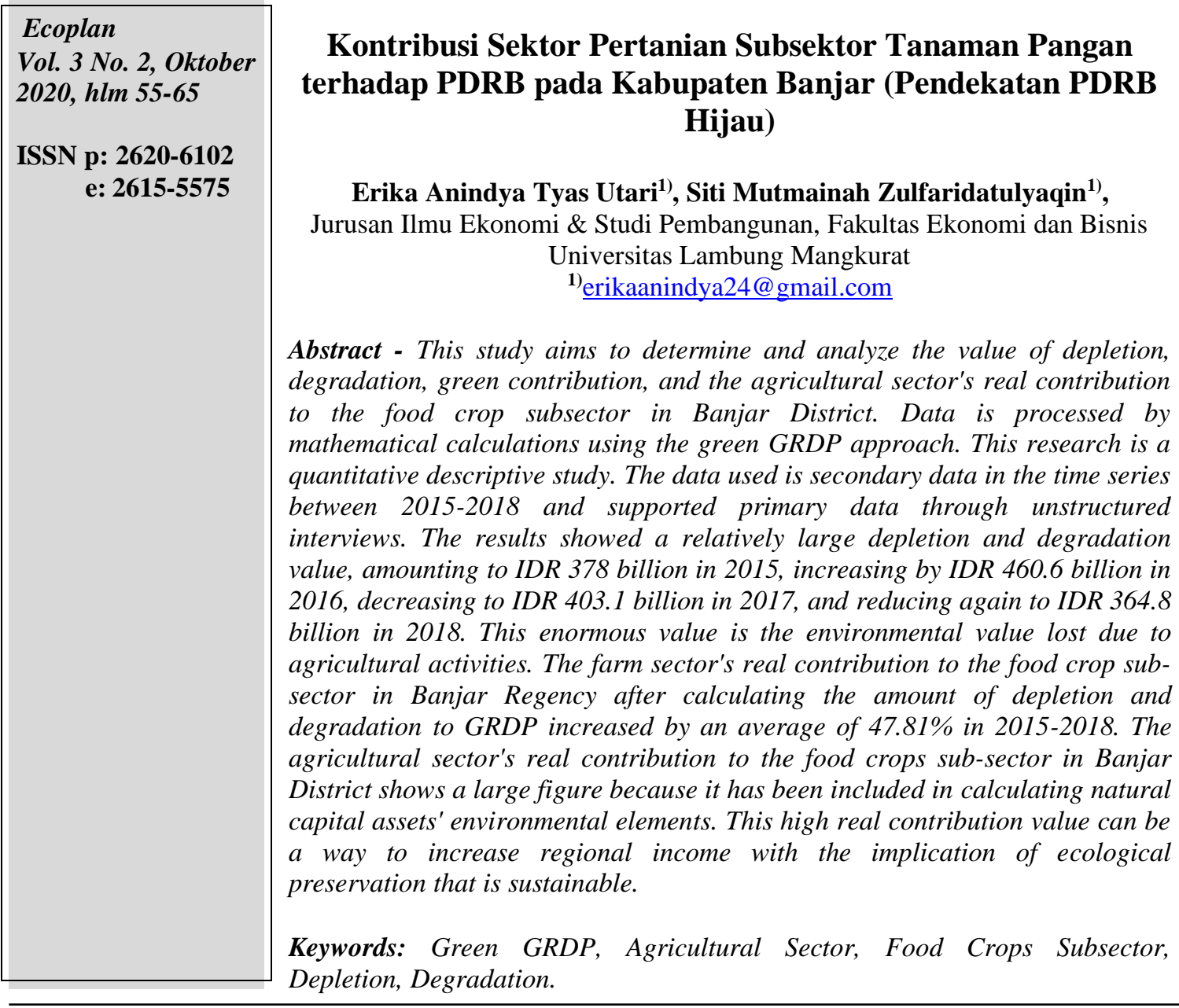

\title{
Kontribusi Sektor Pertanian Subsektor Tanaman Pangan terhadap PDRB pada Kabupaten Banjar (Pendekatan PDRB Hijau)
}

Abstraksi - Penelitian ini bertujuan untuk mengetahui dan menganalisis nilai deplesi, degradasi, kontribusi hijau, serta kontribusi riil sektor pertanian subsektor tanaman pangan di Kabupaten Banjar. Data diolah dengan perhitungan matematis menggunakan pendekatan PDRB hijau. Penelitian ini merupakan penelitian deskriftif kuantitatif dengan jenis data yang digunakan yaitu data sekunder berupa time series antara tahun 2015-2018 dan didukung pula data primer melalui wawancara secara tidak terstruktur. Hasil penelitian menunjukkan nilai deplesi dan degradasi yang relatif besar, sebesar Rp 378 milyar pada tahun 2015, meningkat Rp 460,6 milyar pada tahun 2016, menurun menjadi Rp 403,1 milyar pada tahun 2017, dan menurun lagi menjadi sebesar Rp 364,8 milyar pada tahun 2018. Nilai yang besar tersebut merupakan nilai lingkungan yang hilang akibat kegiatan pertanian. Kontribusi riil sektor pertanian subsektor tanaman pangan di Kabupaten Banjar setelah diperhitungkan nilai deplesi dan degradasi terhadap PDRB meningkat rata-rata sebesar 47,81\% dalam tahun 2015-2018. Kontribusi riil sektor pertanian sub sektor tanaman pangan di Kabupaten Banjar menunjukkan angka yang besar karena sudah dimasukkan perhitungan unsur lingkungan aset modal alami. Nilai kontribusi riil yang tinggi ini dapat menjadi cara meningkatkan pendapatan daerah dengan implikasi pelestarian lingkungan yang berkelanjutan.

Kata Kunci: PDRB Hijau, Sektor Pertanian, Subsektor Tanaman Pangan, Deplesi, Degradasi.

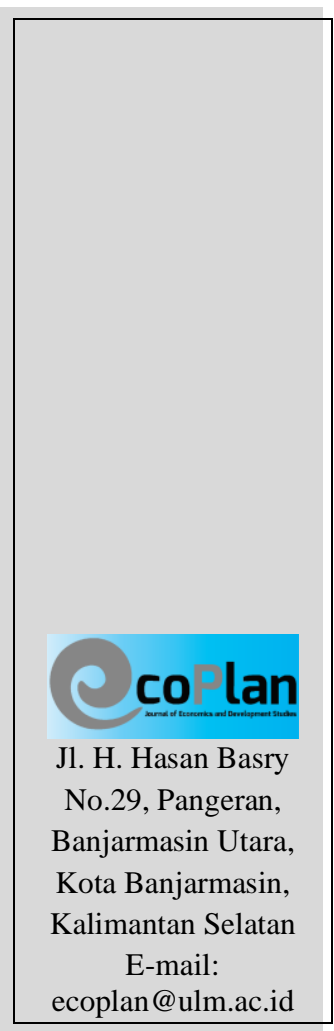




\section{PENDAHULUAN}

Pembangunan merupakan upaya sadar untuk mengelola dan memanfaatkan sumber daya guna meningkatkan mutu kehidupan rakyat. Pertumbuhan ekonomi yang merupakan indikator keberhasilan suatu pembangunan seringkali digunakan untuk mengukur kualitas hidup manusia sehingga semakin tinggi nilai pertumbuhan ekonomi maka semakin tinggi pula taraf hidup manusia. Semakin cepat pertumbuhan ekonomi akan semakin banyak barang sumberdaya yang diperlukan dalam proses produksi yang pada gilirannya akan mengurangi ketersediaan sumberdaya alam sebagai bahan baku yang tersimpan pada sumberdaya alam yang ada. Jadi semakin menggebunya pembangunan ekonomi dalam rangka meningkatkan taraf hidup masyarakat berarti semakin banyak barang sumberdaya yang diambil dari dalam bumi dan akan semakin sedikitlah jumlah persediaan sumberdaya alam tersebut.

Pemanfaatan sumber daya alam secara berlebihan tanpa memperhatikan aspek pelestariannya dapat menurunkan kualitas lingkungan hidup yang akan mengancam swasembada atau ketahanan pangan seluruh penduduk di negara-negara berkembang. Degradasi lingkungan hidup yang semakin parah diberbagai tempat akibat tekanan lonjakan pertumbuhan penduduk terhadap lahan yang ada, telah menurunkan produktivitas lahan pertanian produksi pangan per kapita. Bagi penduduk miskin, pengelolaan dan pengolahan lahan pertanian merupakan sumber nafkah utama, maka kerusakan lingkungan hidup akan sangat berdampak baginya.

Di samping manfaat dan potensi penting sumber pangan tersebut, kontribusi sektor pertanian khususnya subsektor tanaman pangan terhadap pembangunan ekonomi daerah (PDRB) Provinsi Selatan yang dihitung menggunakan pendekatan PDRB Konvensioanl (PDRB Coklat) dapat dilihat dari data BPS Provinsi Kalimantan Selatan (2019) dalam kategori lapangan usaha pertanian, kehutanan, dan perikanan memberikan kontribusi yang relatif besar terhadap PDRB Kalimantan Selatan.

Tabel 1. PDRB ADHB Menurut Lapangan Usaha Kalimantan Selatan (juta rupiah)

\begin{tabular}{|c|c|c|c|c|c|c|}
\hline & $\begin{array}{l}\text { Lapangan Usaha } \\
\text { Industry }\end{array}$ & 2014 & 2015 & 2016 & 2017 & 2018 \\
\hline A & $\begin{array}{l}\text { Pertanian, Kehutanan, dan } \\
\text { Perikanan }\end{array}$ & $18.752 .976,7$ & $20.559 .267,0$ & $21.793 .536,0$ & $23.259 .501,6$ & $24.749 .813,7$ \\
\hline 1 & $\begin{array}{l}\text { Pertanian, } \\
\text { Perburuan, } \\
\text { Pertanian }\end{array}$ & $13.767 .009,2$ & $14.698 .615,3$ & $15.325 .465,9$ & $16.102 .291,0$ & 16.689.651,1 \\
\hline $\mathrm{a}$ & Tanaman Pangan & $5.465 .077,50$ & $6.235 .698,3$ & $6.924 .952,6$ & $7.168 .701,0$ & $7.511 .391,2$ \\
\hline
\end{tabular}

Sumber: BPS Provinsi Kalimantan Selatan (2019)

Sektor pertanian sub sektor tanaman pangan yang termasuk dalam kategori lapangan usaha ini memberikan kontribusi rata-rata terhadap pembangunan daerah provinsi Kalimantan Selatan selama kurun waktu tahun 2014-2018 sekitar $5,69 \%$. Kontribusi sektor pertanian sub sektor tanaman pangan cenderung meningkat dari tahun 2014-2016 dan setelah itu cenderung menurun dari tahun 2016-2018.

Sektor utama penggerak perekonomian Kabupaten Banjar adalah sektor pertanian, kehutanan dan perikanan. Luas daratan yang dimiliki adalah 466.850 ha, dimana seluas 101.769 ha digunakan untuk pertanian. Kabupaten Banjar sendiri merupakan salah satu lumbung padi terbesar kedua di Kalimantan Selatan setelah Kabupaten Barito Kuala. Hal tersebut berarti, Kabupaten Banjar memiliki hasil pendapatan yang besar dari sektor pertanian khususnya subsektor tanaman pangan. Dengan demikian, penelitian ini mencoba untuk mengetahui berapa nilai kontribusi sektor pertanian khususnya subsektor tanaman pangan terhadap PDRB Kabupaten Banjar sebelum dan sesudah dilakukan perhitungan kontribusi hijau.
PDRB konvensional (PDRB Coklat) dianggap belum bisa menunjukkan kesejahteraan daerah yang sesungguhnya, untuk itu diperlukan pendekatan PDRB Hijau (Ratnangingsih, dkk, 2006). PDRB hijau adalah pengembangan lebih lanjut dari PDRB coklat, PDRB hijau adalah koreksi dari konsep PDRB coklat yang tidak mengakomodasi kegagalan pasar. PDRB hijau memiliki konstrain daya lingkungan karena tujuan penerapan PDRB hijau adalah pembangunan yang berkelanjutan.

Pokok-pokok permasalahan yang ingin dibahas penelitian ini adalah: (1) bagaimana nilai deplesi sektor pertanian subsektor tanaman pangan di Kabupaten Banjar? (2) bagaimana nilai kerusakan lingkungan (degradasi) sektor pertanian subsektor tanaman pangan di Kabupaten Banjar? (3) bagaimana PDRB hijau sektor pertanian subsektor tanaman pangan di Kabupaten Banjar? (4) berapa kontibusi riil sektor pertanian subsector tanaman pangan terhadap PDRB menggunakan pendekatan perhitungan PDRB hijau?

Tujuan penelitian ini adalah: (1) mengetahui nilai deplesi sektor pertanian subsektor tanaman pangan di Kabupaten Banjar 
(2) mengetahui nilai kerusakan lingkungan (degradasi) sektor pertanian subsektor tanaman pangan di Kabupaten Banjar (3) mengetahui nilai PDRB hijau sektor pertanian subsektor tanaman

\section{TINJAUAN PUSTAKA \\ Pembangunan Berkelanjutan}

Cita-cita dan agenda utama pembangunan berkelanjutan adalah upaya untuk mensinkronkan, mengintegrasikan dan memberi bobot yang sama bagi tiga aspek utama pembangunan, yaitu aspek ekonomi, aspek sosial-budaya dan aspek lingkungan hidup. Gagasan dibalik pembangunan berkelanjutan adalah pembangunan ekonomi, sosial budaya, dan lingkungan hidup yang harus dipandang sebagai keterkaitan erat satu sama lain, sehingga unsur-unsur dari kesatuan yang saling terkait ini tidak boleh dipisahkan atau dipertentangkan sat dengan yang lainnya. Tujuan yang hendaknya dicapai dengan pembangunan berkelanjutan ini adalah menggeser titik berat pembangunan dari hanya pembangunan ekonomi menjadi juga mencakup pembangunan sosialbudaya dan lingkungan hidup. (A. Sonny Keraf, 2010).

Jika diukur secara kuantitatif, kerugian yang disebabkan oleh dikorbankannya aspek sosial-budaya dan aspek lingkungan hidup akan terlihat bahwa apa yang selama ini disebut sebagai pertumbuhan ekonomi positif, sesungguhnya adalah pertumbuhan negatif. Karena, biaya untuk kerugian sosial-budaya dan lingkungan hidup ternyata sangat banyak. Berarti, pertumbuhan ekonomi yang positif tersebut ternyata semu, dan sia-sia dibangun kalau pada akhirnya yang kita tuai adalah adalah kerusakan sosial-budaya dan lingkungan hidup.

Lingkungan dipandang sebagai aset utama yang menyediakan kebutuhan umat manusia. Dengan demikian, kebutuhan manusia merupakan bagian yang tidak terpisahkan dari sistem ekonomi dan sekaligus yang menjamin keberlangsungan sistem ekonomi itu sendiri. Lingkungan menyediakan sistem pendukung kehidupan untuk mempertahankan keberadaan umat manusia. Usaha mengatasi proses depresiasi dari asset lingkungan bukan hanya untuk kepentingan konservasi dan pelestarian lingkungan itu sendiri, tetapi yang lebih penting adalah bagaimana sistem ekonomi dalam jangka panjang bisa memenuhi kebutuhan umat manusia yang pandangannya tidak hanya generasi sekarang, tetapi juga generasi yang akan datang.

\section{Sektor Pertanian Subsektor Tanaman Pangan}

Pertanian adalah sejenis proses produksi khusus yang didasarkan atas proses pertumbuhan tanaman dan hewani (Satari, 1999). Pertanian diterjemahkan dari kata agriculture berasal dari pangan di Kabupaten Banjar (4) mengetahui nilai kontibusi riil sektor pertanian subsektor tanaman pangan Kabupaten Banjar terhadap PDRB menggunakan pendekatan PDRB hijau. bahasa latin yaitu terdiri dari "ager" yang berarti lapangan/tanah/lading/tegalan dan "cultura" yang berarti mengamati/memelihara/membajak. Anwas Adiwilaga (1972 dalam Rodjak, 2004) mendefinisikan pertanian sebagai kegiatan memelihara tanaman dan ternak pada sebidang tanah, tanpa menyebabkan tanah tersebut rusak untuk produksi selanjutnya.

Subsektor tanaman pangan meliputi semua kegiatan ekonomi yang menghasilkan komoditi bahan makanan seperti padi, jagung, ketela pohon, ketela rambat, ubi-ubian, kacang tanah, kacang kedelai, sayur-sayuran, buahbuahan, padi-padian, serta bahan makanan lainnya.

Produk Domestik Regional Bruto Konvensional Jumlah nilai tambah yang dihasilkan oleh seluruh unit ekonomi di suatu wilayah (BPS, 2016). PDRB hingga saat ini masih sangat popular digunakan sebagai salah satu indikator ekonomi makro. Disamping untuk mengukur pertumbuhan ekonomi, angka PDRB sektoral juga bermanfaat untuk mengukur besar konstribusi masing-masing sektor dalam membentuk PDRB, yang secara langsung juga dapat menggambarkan pertumbuhan ekonomi pada masing-masing sektor. Perencanaan pembangunan daerah hingga saat ini masih menjadikan PDRB sebagai salah satu landasan prioritas dan sasaran program, besarnya nilai PDRB sektor selalu dijadikan sebagai ukuran keberhasilan program/kinerja pemerintah.

\section{Produk Domestik Regional Bruto Hijau}

PDRB Hijau merupakan metode baru yang menampilkan indikator kegiatan ekonomi dan sekaligus menampilkan nilai deplesi dan degradasi lingkungan sehingga struktur perekonomian dapat dilihat secara lebih realistis (Soeparmoko, 2006). Parameter pengukuran keberhasilan pembangunan harus mengakomodasi aspek keberlanjutan lingkungan. Di Indonesia sendiri, dalam melaksanakan ketentuan Pasal 43 ayat (4) dan Pasal 55 ayat (4) Undang-Undang Nomor 32 Tahun 2009 tentang Perlindungan dan Pengelolaan Lingkungan Hidup, ditetapkan Peraturan Pemerintah Nomor 46 Tahun 2017 yang pada Pasal 1 ayat (7) disebutkan bahwa "Produk Domestik Bruto dan Produk Domestik Regional Bruto yang mencakup Penyusutan Sumber Daya Alam dan Kerusakan Lingkungan Hidup yang selanjutnya disebut PDB atau PDRB LH adalah perhitungan alternatif yang memperhitungkan 
penyusutan sumber daya alam dan kerusakan

\section{Deplesi}

Deplesi adalah berkurangnya atau menyusutnya nilai dari sumber daya alam seperti lahan, hutan, bahan tambang, dan sumber daya alam lainnya (Zaki Baridwan, 1999). Deplesi sumberdaya pangan adalah hilangnya tanaman pangan yang tercermin dari volume produksi tanaman pangan yang dipanen. Menurut Suparmoko (2006) yang harus diidentifikasi dalam menghitung deplesi sumberdaya alam adalah jenis dan volume sumberdaya yang digunakan langsung dari alam (extractive use). Nilai deplesi diperoleh dengan mengalikan volume pengambilan masing-masing jenis sumberdaya alam dengan unit rent atau unit net price. Untuk menghitung unit rent adalah dengan mengurangkan seluruh biaya pengambilan dari nilai jual sumberdaya alam termasuk nilai laba (balas jasa pengeluaran investasi) yang layak diterima oleh pemrakarsa.

\section{Degradasi}

Menurut Suparmoko (2006) degradasi sumberdaya alam dan lingkungan adalah menurunnya kualitas lingkungan atau fungsi lingkungan yang tercermin pada menurunnya kemampuan lingkungan dalam menghasilkan barang sumberdaya alam (natural resources inputs), dalam memberikan jasa lingkungan (environmental services dan biodivesity services) serta kesenangan langsung (amenity services), maupun sebagai pengolah limbah secara alami (natural assimilator). Degradasi sumberdaya tanah untuk lahan pertanian bisa dikatakan sebagai peristiwa menurunnya kualitas tanah pertanian, sehingga produktivitas pertanian terganggu dan dapat menimbulkan berkurangnya jumlah hasil produksi pertanian dalam memenuhi kebutuhan pangan manusia. Menghitung nilai degradasi

\section{METODE PENELITIAN}

Ruang lingkup penelitian ini adalah wilayah Provinsi Kalimantan Selatan khususnya Kabupaten Banjar. Penelitian dilakukan terhadap sektor pertanian sub sektor tanaman pangan di Kabupaten Banjar Provinsi Kalimantan Selatan mengenai bagaimana seharusnya PDRB Hijau dimanfaatkan di Kabupaten Banjar. Penelitian ini adalah penelitian deskriptif kuantitatif dengan mengumpulkan dan menganalisis data dari Badan Pusat Statistik Provinsi Kalimantan Selatan, Badan Pusat Statistik Kabupaten Banjar, Dinas Tanaman Pangan dan Holtikultura Kabupaten Banjar, dan pihak-pihak lain yang terkait. Pendekatan yang digunakan dalam penelitian ini lingkungan hidup".

dilakukan dengan mengidentifikasi kerusakan atau degradasi sumber daya. Selanjutnya mengkuantifikasi volume degradasi, dalam hal ini berapa banyak unsur hara yang hilang. Itu semua dinyatakan dalam jumlah atau volume tertentu, kemudian dihitung nilai ekonomisnya. Pendekatan yang umum dipakai adalah menghitung biaya untuk mengembalikan kondisi lingkungan yang rusak itu menjadi seperti semula (replacement costs).

\section{Penelitian Terdahulu}

Penelitian terdahulu oleh Lestari Rahayu Waluyati, Any Suryantinim Herman Masbaitubun, Laurentius H Maturbongs \& Nobertus Citra Irawan (2010) yang berjudul "Produk Domestik Regional Bruto (PDRB) Hijau Sektor Pertanian di Kabupaten Jayapura" menunjukkan peningkatan kontribusi riil sektor pertanian di Kabupaten Jayapura setelah dilakukan perhitungan PDRB Hijau sebesar rata-rata 39,12\% dalam 3 tahun.

M. Anshar Nur, Siti Mutmainah Zulfaridatul Yaqin \& Ahmad Yunani (2018) dengan judul "Kontribusi Sektor Kehutanan terhadap Pembangunan Regional Provinsi Kalimantan Selatan (Pendekatan Perhitungan PDRB Hijau)" menunjukkan hasil kontribusi riil penerimaan daerah sektor kehutanan dengan menambahkan jumlah PDRB Konvensional dengan nilai depresiasi sumber daya hutan lebih besar dibandingkan dengan kontribusi PDRB Konvensional.

Yugi Setyarko (2008) dengan judul "Kontribusi Hijau Sektor Kehutanan pada PDRB dan Pembangunan Regional Kabupaten Batang Hari Provinsi Jambi" menunjukkan hasil perhitungan nilai kontribusi hijau negatif, bahwa kontribusi coklat sektor kehutanan PDRB Kabupaten Batang Hari lebih kecil dibandingkan dengan modal pada sumberdaya alam dan lingkungan yang digunakan.

adalah pendekatan perhitungan PDRB Hijau. Jenis data yang digunakan adalah data sekunder berupa data time series dan dokumen-dokumen yang juga di dukung data primer dengan melakukan wawancara (tidak terstruktur) dengan pihak terkait.

\section{Teknik Analisis Data}

Teknik analisis data menggunakan pendekatan perhitungan PDRB Hijau yang telah dipublikasikan oleh Suparmoko (2006).

1. Deplesi Sumber Daya Pertanian

Besar nilai deplesi sumber daya pertanian diperoleh dari hasil perkalian antara volume sumberdaya yang termanfaatkan (dalam hal ini sumber daya tanah) untuk 
proses produksi dikalikan dengan unit rent.

Unit Rent atau $\mathbf{R i}=\mathbf{H i}-\mathbf{P i}-\mathbf{L i}$

dimana: $\mathrm{Ri}=$ Unit rent tanaman pangan $\mathrm{i}(\mathrm{Rp} / \mathrm{kg})$

$\mathrm{Hi}=$ Perdapatan per hektar tanaman pangan i $(\mathrm{Rp} / \mathrm{kg})$

$\mathrm{Pi}=$ Biaya produksi tanaman pangan $\mathrm{i}$ $(\mathrm{Rp} / \mathrm{kg})$

$\mathrm{Li}=$ Laba layak per unit (yang diasumsikan dengan suku bunga Bank Indonesia)

Deplesi atau Di = Ri x Vi

dimana: $\mathrm{Di}=$ Deplesi tanaman pangan $\mathrm{i}(\mathrm{Rp})$

$\mathrm{Ri}=$ Unit rent tanaman pangan $\mathrm{i}(\mathrm{Rp} / \mathrm{kg})$

$\mathrm{Vi}=$ Volume produksi jenis tanaman pangan i $(\mathrm{kg})$

2. PDRB Semi Hijau Sektor Pertanian

PDRB Semi Hijau = PDRB

Konvensional Sektor Pertanian Sub

Sektor Tanaman Pangan - Deplesi

Sumber Daya Pertanian

3. Degradasi Sumber Daya Tanah

Degradasi sumber daya tanah ini akan tercermin pada menurunnya kualitas tanah atau kesuburan tanah. Oleh karena itu penilaiannya akan ditempuh dengan pendekatan penurunan produktivitas.

$$
\boldsymbol{V}_{\boldsymbol{p}}=\Delta \boldsymbol{L}_{\boldsymbol{h}} \boldsymbol{x} \Delta \boldsymbol{P}_{\boldsymbol{l h}}
$$

dimana: $\mathrm{V}_{\mathrm{p}}=$ Degradasi produksi pertanian $(\mathrm{Rp})$

$\mathrm{L}_{\mathrm{h}}=$ Luas degradasi lahan pertanian (ha)

$\mathrm{P}_{\mathrm{lh}}=$ Produktivitas lahan per hektar $(\mathrm{Rp})$

$\Delta=$ Perubahan

$$
P_{h}=f(N P K)
$$

dimana: $\mathrm{P}_{\mathrm{lh}}=$ Produktivitas lahan per hektar

$\mathrm{N}=$ Kandungan mineral $\mathrm{N}$

$\mathrm{P}=$ Kandungan mineral $\mathrm{P}$

$\mathrm{K}=$ Kandungan mineral $\mathrm{K}$

4. PDRB Hijau

PDRB Hijau $=$ PDRB Konvensional

Sektor Pertanian Sub Sektor Tanaman

Pangan - Deplesi Sumber Daya

Pertanian - Degradasi Sumber Daya

Tanah

5. Kontribusi Riil

Kontribusi Riil $=$ PDRB Konvensional

Sektor Pertanian Sub Sektor Tanaman Pangan + Deplesi Sumber Daya Pertanian + Degradasi Sumber Daya Tanah

Tabel 2. PDRB Konvensional Sub Sektor Tanaman Pangan

\begin{tabular}{cccc}
\hline TAHUN & $\begin{array}{c}\text { PDRB SUB SEKTOR TANAMAN } \\
\text { PANGAN (Milyar Rp) }\end{array}$ & $\begin{array}{c}\text { PDRB KAB. BANJAR } \\
\text { (Milyar Rp) }\end{array}$ & $\begin{array}{c}\text { KONTRIBUSI } \\
(\boldsymbol{\%})\end{array}$ \\
\hline 2015 & 782,67 & $12.480,88$ & 6,27 \\
2016 & 870,30 & $13.339,97$ & 6,52 \\
2017 & 837,50 & $14.483,61$ & 5,78 \\
2018 & 871,06 & $15.682,89$ & 5,55 \\
\hline
\end{tabular}

Sumber: BPS Kab. Banjar (2019)

\section{HASIL DAN ANALISIS}

\section{Kontribusi Sub Sektor Tanaman Pangan Terhadap PDRB}

Kontribusi sub sektor tanaman pangan dapat dilihat pada tabel 2 yang bersumber dari BPS Kabupaten Banjar. Nilai kontribusi sub sektor tanaman pangan berfluktuasi dari tahun 2015 hingga tahun 2018. yaitu setinggi $6,27 \%$ pada tahun 2015 , meningkat menjadi $6,52 \%$ pada tahun 2016, kemudian menurun menjadi $5,78 \%$ pada tahun 2017 , dan menurun lagi menjadi $5,55 \%$ pada tahun 2018.

\section{Deplesi Sumber Daya Pertanian}

1. Produksi Tanaman Pangan

Produksi tanaman pangan dapat dilihat pada tabel 3. Jumlah produksi tanaman pangan pada berbagai jenis pangan menunjukkan angka yang fluktuatif setiap tahunnya. Fluktuasi angka jumlah produksi disebabkan oleh luas panen pertanian dan hasil produksi yang berubah-rubah. Hal-hal tersebut terjadi karena banyak faktor. Kinerja produksi tanaman pangan yang masih dipengaruhi oleh iklim, di beberapa daerah terjadi banjir sedangkan di beberapa daerah lainnya terjadi kekeringan. Selain itu, terjadi pula serangan penyakit dan hama, yang kemudian menyebabkan banyak terjadinya sawah yang gagal panen. Serta alih fungsi lahan yang tidak bijaksana menjadi lahan komersil.

Untuk melakukan perhitungan penyesuaian satuan volume produksi dari ton menjadi kilogram. Perubahan satuan tersebut guna memudahkan perhitungan, karena data harga jenis komoditi menggunakan satuan rupiah per kilogram. Selain itu diperlukan perbandingan antara volume produksi dengan luas panen agar mengetahui berapa kilogram volume produksi yang tercipta dalam satu hektar nya. 
Utari, E.A.T., Zulfaridatulyaqin, S.M.

Tabel 3. Produksi Tanaman Pangan Kabupaten Banjar

\begin{tabular}{clrr}
\hline \multirow{2}{*}{ TAHUN } & \multicolumn{1}{c}{ JENIS } & $\begin{array}{c}\text { LUAS } \\
\text { PANEN } \\
\text { KOMODITI }\end{array}$ & $\begin{array}{c}\text { JUMLAH } \\
\text { PRODUKSI } \\
\text { (Ton) }\end{array}$ \\
\hline \multirow{2}{*}{2015} & Padi Sawah & $61.004,00$ & \multicolumn{1}{c}{$235.504,00$} \\
& Padi Ladang & $9.657,00$ & $25.755,00$ \\
& Kedelai & $1.164,00$ & $1.377,00$ \\
& Jagung & 494,00 & $1.971,00$ \\
\hline \multirow{2}{*}{2016} & Padi Sawah & $63.771,50$ & $242.947,00$ \\
& Padi Ladang & $10.429,00$ & $34.921,00$ \\
& Kedelai & $2.615,00$ & $3.868,00$ \\
& Jagung & $1.808,90$ & $9.334,00$ \\
\hline \multirow{2}{*}{$\mathbf{2 0 1 7}$} & Padi Sawah & $56.190,30$ & $218.855,00$ \\
& Padi Ladang & $11.132,00$ & $31.532,41$ \\
& Kedelai & 37,00 & 47,00 \\
& Jagung & $2.837,90$ & $17.835,00$ \\
\hline \multirow{2}{*}{$\mathbf{2 0 1 8}$} & Padi Sawah & $57.598,70$ & $200.026,00$ \\
& Padi Ladang & $10.664,00$ & $36.491,00$ \\
& Kedelai & 905,00 & $1.607,90$ \\
& Jagung & $1.365,00$ & $7.830,39$ \\
\hline \multirow{2}{*}{ Sumber: DTPH Kab. Banjar } & &
\end{tabular}

2. Unit Rent

2.1. Harga Tanaman Pangan

Tabel 4. Rata-rata Harga Komoditi Tanaman Pangan Ditingkat Produsen ( Rp/Kg)

\begin{tabular}{lrrrr}
\hline \multirow{2}{*}{$\begin{array}{c}\text { JENIS } \\
\text { KOMODITI }\end{array}$} & \multicolumn{4}{c}{ TAHUN } \\
\cline { 2 - 5 } Padi Sawah & $\mathbf{2 0 1 5}$ & $\mathbf{2 0 1 6}$ & $\mathbf{2 0 1 7}$ & $\mathbf{2 0 1 8}$ \\
Padi Ladang & 4.700 & 4.800 & 4.650 & 4.950 \\
Kedelai & 6.200 & 6.200 & 6.000 & 5.800 \\
Jagung & 8.500 & 7.900 & 7.900 & 8.300 \\
\hline
\end{tabular}

Sumber: DTPH Prov. Kalimantan Selatan

Untuk melakukan perhitungan deplesi, harga jenis komoditi tanaman pangan dikalikan terlebih dahulu dengan perbandingan antara akan mendapatkan perkiraan pendapatan per hektar petani. Perkiraan pendapatan per hektar volume produksi dan luas panen, dan hasilnya dapat dilihat pada tabel 5 berikut.

Tabel 5. Perkiraan Pendapatan Petani per Hektar (Rp)

\begin{tabular}{lcccc}
\multicolumn{5}{c}{ Tabel 5. Perkiraan Pendapatan Petani per Hektar (Rp) } \\
\cline { 2 - 5 } \multicolumn{1}{c}{ JENIS } & \multicolumn{4}{c}{ TAHUN } \\
KOMODITI & $\mathbf{2 0 1 5}$ & $\mathbf{2 0 1 6}$ & $\mathbf{2 0 1 7}$ & $\mathbf{2 0 1 8}$ \\
\hline Padi Sawah & 18.144 .200 & 18.286 .313 & 18.111 .235 & 17.190 .122 \\
Padi Ladang & 16.535 .259 & 20.760 .399 & 16.995 .550 & 19.846 .943 \\
Kedelai & 10.055 .412 & 11.685 .354 & 10.035 .135 & 14.746 .505 \\
Jagung & 25.136 .235 & 18.060 .147 & 23.252 .934 & 18.070 .131 \\
\hline Sumber: Data diolah & & \multicolumn{4}{c}{}
\end{tabular}


Utari, E.A.T., Zulfaridatulyaqin, S.M.

2.2. Biaya Produksi Tanaman Pangan

Tabel 6. Biaya Produksi Jenis Tanaman Pangan per Hektar (Rp)

\begin{tabular}{lrrrr}
\hline BIAYA PRODUKSI & PADI SAWAH & LADANG & KEDELAI & \multicolumn{1}{c}{ JAGUNG } \\
\hline Bibit/Benih & 514.360 & 401.960 & 591.020 & 899.120 \\
Pupuk & 1.278 .000 & 710.590 & 449.180 & 1.370 .090 \\
Pestisida & 569.550 & 296.590 & 363.570 & 352.020 \\
Tenaga Kerja & 6.615 .190 & 5.074 .310 & 4.272 .070 & 4.951 .130 \\
Sewa Lahan & 3.472 .360 & 1.204 .780 & 2.613 .330 & 1.792 .480 \\
Sewa alat & 398.810 & 236.570 & 208.440 & 230.030 \\
Penyusutan & 211.390 & 163.910 & 179.170 & 155.420 \\
Bahan Bakar & 127.900 & 107.960 & 113.460 & 132.570 \\
Lainnya & 371.670 & 259.040 & 255.610 & 314.280 \\
\hline TOTAL & 13.559 .230 & 8.455 .710 & 9.045 .850 & 10.197 .140 \\
\hline
\end{tabular}

Sumber: BPS Indonesia (2017)

Data di dapat dari publikasi BPS Nasional pada tahun 2017. Publikasi biaya produksi terbit setiap 3 tahun sekali, karena dalam setahun perubahan biaya produksi tidak lah banyak mengalami perubahan (tidak signifikan).

\subsection{Suku Bunga}

Suku bunga untuk menghitung laba layak kredit investasi tahunan untuk persero hasil publikasi Badan Pusat Statistik. Besarnya nilai suku bunga didasarkan pada suku bunga bulan Januari tahun bersangkutan.

Setelah diperoleh dan disesuaikan datadata di atas, maka hasil perhitungan unit rent dapat dilihat pada tabel 8 berikut. produksi tanaman pangan merupakan suku bunga

Tabel 7. Suku Bunga Kredit Investasi

\begin{tabular}{cc}
\hline TAHUN & BUNGA KREDIT INVESTASI $(\%)$ \\
\hline 2015 & 11,47 \\
2016 & 11,34 \\
2017 & 10,45 \\
2018 & 10,26 \\
\hline Sumber: BPS Indonesia (2019) &
\end{tabular}

Tabel 8. Unit Rent Komoditi Tanaman Pangan (Rp)

\begin{tabular}{ccccc}
\hline \multirow{2}{*}{ JENIS } & \multicolumn{4}{c}{ TAHUN } \\
\cline { 2 - 5 } KOMODITI & $\mathbf{2 0 1 5}$ & $\mathbf{2 0 1 6}$ & $\mathbf{2 0 1 7}$ & $\mathbf{2 0 1 8}$ \\
\hline Padi Sawah & 4.059 .074 & 4.191 .032 & 4.076 .321 & 3.258 .363 \\
Padi Ladang & 7.152 .825 & 10.909 .337 & 7.647 .427 & 10.222 .492 \\
Kedelai & 893.766 & 2.340 .184 & 885.905 & 5.115 .768 \\
Jagung & 13.225 .581 & 6.971 .342 & 11.691 .463 & 7.065 .222 \\
\hline
\end{tabular}

Sumber: Data diolah

Nilai unit rent komoditi tanaman pangan dari tahun 2015 hingga 2018 mengalami fluktuasi disebabkan oleh luas panen dan jumlah produksi yang juga mengalami perubahan terus-menerus setiap tahunnya. Selanjutnya besar nilai deplesi sumber daya pertanian (tabel 9) diperoleh dari hasil perkalian antara volume sumberdaya yang termanfaatkan (dalam hal ini sumber daya tanah) untuk proses produksi dikalikan dengan unit rent. 
Utari, E.A.T., Zulfaridatulyaqin, S.M.

Tabel 9. Deplesi Sumber Daya Pertanian

\begin{tabular}{ccccc}
\hline \multirow{2}{*}{ JENIS } & \multicolumn{4}{c}{ TAHUN } \\
\cline { 2 - 5 } KOMODITI & $\mathbf{2 0 1 5}$ & $\mathbf{2 0 1 6}$ & $\mathbf{2 0 1 7}$ & $\mathbf{2 0 1 8}$ \\
\hline Padi Sawah & $247.619,77$ & $267.268,38$ & $229.049,69$ & $187.677,46$ \\
Padi Ladang & $69.074,83$ & $113.773,48$ & $85.131,15$ & $109.012,66$ \\
Kedelai & $1.040,34$ & $6.119,58$ & 32,78 & $4.629,77$ \\
Jagung & $6.533,44$ & $12.610,46$ & $33.179,20$ & $9.644,03$ \\
\hline Total & $\mathbf{3 2 4 . 2 6 8 , 3 8}$ & $\mathbf{3 9 9 . 7 7 1 , 8 9}$ & $\mathbf{3 4 7 . 3 9 2 , 8 2}$ & $\mathbf{3 1 0 . 9 6 3 , 9 2}$ \\
\hline Sumber: Data diolah & & & &
\end{tabular}

Terlihat nilai total deplesi sumber daya pertanian berfluktuasi setiap tahunnya sesuai dengan nominal unit rent yang juga berfluktuasi. Kondisi tersebut juga menunjukkan semakin besar volume produksi yang diambil maka semakin besar pula nilai deplesinya. Untuk komoditi jagung nilai deplesinya semakin meningkat, hal ini sejalan dengan nilai produktivitasnya yang semakin meningkat pula dari tahun 2015 hingga 2017.

\section{Degradasi Sumber Daya Tanah}

Dari hasil wawancara yang dilakukan dengan Kepala Balai Penyuluhan Pertanian di Kecamatan Aranio, pemupukan berimbang untuk ke empat komoditas yang di teliti memiliki jumlah rata-rata dan waktu pemupukan yang berbedabeda dalam satu hektar nya. Untuk padi sawah diperlukan 3 jenis pupuk yaitu pupuk urea sebesar
$100 \mathrm{~kg}$, pupuk SP36 sebesar $100 \mathrm{~kg}$ dan pupuk NPK Ponshka sebesar $150 \mathrm{~kg}$. Padi 62ading hanya diperlukan 2 jenis pupuk yaitu pupuk urea sebesar $250 \mathrm{~kg}$ dan pupuk SP36 sebesar $150 \mathrm{~kg}$. Kedelai memerlukan 2 jenis pupuk yaitu SP36 sebesar $150 \mathrm{~kg}$ dan pupuk NPK Ponshka sebesar $300 \mathrm{~kg}$. Sedangkan komoditi jagung memerlukan 3 jenis pupuk yaitu pupuk urea sebesar $300 \mathrm{~kg}$, pupuk SP36 sebesar $200 \mathrm{~kg}$ dan pupuk NPK sebesar 600 $\mathrm{kg}$ dalam 2 kali pemupukan.

Harga pupuk per kilogram seperti pada tabel 9 dibawah di tidak mengalami perubahan harga selama tahun 2015 hingga tahun 2018. Harga pupuk ini diperlukan untuk mendapatkan biaya produktivitas lahan per hektar (tabel 11), ditunjukkan dengan kandungan unsur hara dalam tanah dikalikan harga pupuk.

Tabel 10. Harga Pupuk per Kilogram

\begin{tabular}{cc}
\hline JENIS PUPUK & HARGA \\
\hline Urea & 1.800 \\
SP36 & 2.000 \\
NPK Ponshka & 2.300 \\
\hline \multicolumn{2}{c}{ Sumber: BPS Kab. Banjar }
\end{tabular}

Tabel 11. Biaya Produktivitas Lahan per Hektar (Rp)

\begin{tabular}{cr}
\hline \multicolumn{2}{c}{ BIAYA DEGRADASI LAHAN } \\
\hline Padi Sawah & 725.000 \\
Padi Ladang & 750.000 \\
Kedelai & 990.000 \\
Jagung & 2.320 .000 \\
\hline \multicolumn{2}{c}{ Sumber: Data diolah }
\end{tabular}

Selanjutnya biaya produktivitas lahan per hektar ini dikalikan dengan luas lahan panen setiap tahunnya dari masing-masing komoditas untuk mendapatkan hasil degradasi sumber daya tanah (tabel 12). Pendekatan yang umum dipakai dalam menghitung degradasi adalah dengan menghitung biaya untuk mengembalikan kondisi lingkungan yang rusak itu menjadi seperti semula (replacement costs). 
Utari, E.A.T., Zulfaridatulyaqin, S.M.

Tabel 12. Degradasi Sumber Daya Tanah

\begin{tabular}{ccccc}
\hline JENIS & \multicolumn{5}{c}{ (2015 } & $\mathbf{2 0 1 6}$ & $\mathbf{2 0 1 7}$ & $\mathbf{2 0 1 8}$ \\
\hline KOMODITI & 44.227 .900 .000 & 46.234 .337 .500 & 40.737 .967 .500 & 41.759 .057 .500 \\
Padi Sawah & 7.242 .750 .000 & 7.821 .750 .000 & 8.349 .000 .000 & 7.998 .000 .000 \\
Padi Ladang & 1.152 .360 .000 & 2.588 .850 .000 & 36.630 .000 & 895.950 .000 \\
Kedelai & 1.146 .080 .000 & 4.196 .648 .000 & 6.583 .928 .000 & 3.166 .800 .000 \\
Jagung & $\mathbf{5 3 . 7 6 9 . 0 9 0 . 0 0 0}$ & $\mathbf{6 0 . 8 4 1 . 5 8 5 . 5 0 0}$ & $\mathbf{5 5 . 7 0 7 . 5 2 5 . 5 0 0}$ & $\mathbf{5 3 . 8 1 9 . 8 0 7 . 5 0 0}$ \\
Total & & & & \\
\hline
\end{tabular}

Sumber: Data diolah

Nilai degradasi seperti terlihat pada tabel 12 diatas, menunjukkan angka total yang meningkat pada tahun 2016, kemudian mengalami penurunan pada tahun 2017 dan 2018 . Hal tersebut menunjukkan bahwa semakin besar volume dan besaran luas panen, maka semakin besar juga nilai degradasi sumber daya tanah. Data ini juga menunjukkan relatif besarnya degradasi pada lahan komoditas tanaman pangan yang mencerminkan diperlukannya intensifikasi pengelolaan komoditas tanaman pangan di Kabupaten Banjar. Selain itu, kualitas sumberdaya tanah di Kabupaten Banjar terus menurun akibat konversi lahan dan degradasi yang disebabkan oleh sistem pengelolaan tidak baik.

\section{Kontribusi PDRB Hijau dan Kontribusi Riil}

Hasil kontribusi hijau yang digunakan dengan pendekatan PDRB hijau (terlihat pada tabel 13) menunjukkan angka yang lebih kecil dibandingkan kontribusi coklat (PDRB coklat). Kecilnya angka tersebut menunjukkan bahwa Kabupaten Banjar telah mengorbankan aset alami dari sumber daya pertanian yang dimiliki, berupa deplesi dan degradasi dari sub sektor tanaman pangan yang cukup besar dan belum diperhitungkan sebagai nilai tambah dalam perhitungan PDRB konvensional.

Sebaliknya, nilai kontribusi riil sub sektor tanaman pangan terlihat jauh lebih besar dibandingkan dengan nilai kontribusi hijau serta sudah dimasukkannya nilai penyusutan modal alami pertanian. Besarnya nominal kontribusi riil ini dapat menjadi salah satu tolak ukur dalam meningkatkan pendapatan daerah dengan implikasi pelestarian lingkungan yang berkelanjutan. Sesuai dengan pengertian pembangunan berkelanjutan sebagai pembangunan yang memenuhi kebutuhan generasi sekarang tanpa mengorbankan kemampuan generasi yang akan datang untuk memenuhi kebutuhannya, maka seyogyanya pengukuran keberhasilan pembangunan harus mengakomodasi aspek keberlanjutan lingkungan tersebut.

Tabel 13. PDRB Hijau dan Kontribusi Riil Sub Sektor Tanaman Pangan Kabupaten Banjar (Juta Rp)

\begin{tabular}{|c|c|c|c|c|c|}
\hline \multirow{2}{*}{ No. } & \multirow{2}{*}{ KATEGORI } & \multicolumn{4}{|c|}{ TAHUN } \\
\hline & & 2015 & 2016 & 2017 & 2018 \\
\hline & $\begin{array}{l}\text { PERTANIAN, } \\
\text { KEHUTANAN, DAN }\end{array}$ & & & & \\
\hline 1 & PERIKANAN & $2.289 .944,78$ & 2.506.977,95 & $2.623 .063,44$ & $2.827 .846,53$ \\
\hline & $\begin{array}{l}\text { Pertanian, Peternakan, } \\
\text { Perburuan dan Jasa }\end{array}$ & $1.431 .174,36$ & $1.542 .468,63$ & $1.563 .118,61$ & $1.635 .712,83$ \\
\hline 1.1 & Pertanian & & & & \\
\hline 1.1.1 & $\begin{array}{l}\text { Tanaman Pangan } \\
\text { DEPLESI SUMBER }\end{array}$ & $782.666,02$ & $870.302,82$ & $837.504,67$ & $871.064,45$ \\
\hline 2 & DAYA PERTANIAN & $324.268,38$ & $399.771,89$ & $347.392,82$ & $310.963,92$ \\
\hline 3 & $\begin{array}{l}\text { PDRB SEMI HIJAU } \\
\text { DEGRADASI } \\
\text { SUMBER DAYA }\end{array}$ & $458.397,64$ & $470.530,92$ & $490.111,85$ & $560.100,53$ \\
\hline 4 & TANAH & $53.769,09$ & $60.841,59$ & $55.707,53$ & $53.819,81$ \\
\hline 5 & $\begin{array}{l}\text { PDRB HIJAU } \\
\text { NILAI TAMBAH }\end{array}$ & $404.628,55$ & $409.689,34$ & $434.404,32$ & $506.280,73$ \\
\hline 6 & $\begin{array}{l}\text { PDRB HIJAU } \\
\text { KENAIKAN }\end{array}$ & $1.160 .703,48$ & $1.330 .916,30$ & $1.240 .605,02$ & $1.235 .848,18$ \\
\hline 7 & $\begin{array}{l}\text { KONTRIBUSI } \\
\text { PERSENTASE }\end{array}$ & $378.037,47$ & $460.613,48$ & $403.100,35$ & $364.783,73$ \\
\hline 8 & KENAIKAN (\%) & 48,30 & 52,93 & 48,13 & 41,88 \\
\hline
\end{tabular}




\section{PENUTUP}

\section{Keterbatasan Penelitian}

Biaya produksi komoditi tanaman pangan yang diambil merupakan nilai dalam 3 tahun, sehingga belum menunjukkan hasil perhitungan yang lebih relevan sesuai dengan nilai inflasi per tahun nya. Kuantitas pupuk yang diperlukan dalam menghitung degradasi lahan, masih berupa nilai rata-rata. Pendekatan yang digunakan pun masih sederhana menggunakan pendekatan umum, sehingga nilai-nilai unsur lain dalam menghitung degradasi belum dimasukkan.

\section{Kesimpulan}

Kesimpulan dalam penelitian ini adalah (1) nilai deplesi menunjukkan angka yang cukup besar, namun berfluktuasi yang menunjukkan bahwa semakin besar volume produksi maka semakin besar pula nilai deplesinya, sesuai dengan luas panen dan volume produksi yang selalu berubah-ubah karena banyak faktor, diantaranya gagal panen dan perubahan luas lahan akibat konversi lahan (2) Nilai degradasi menunjukkan angka yang berfluktuasi menunjukkan bahwa semakin besar volume produksi yang di ambil maka semakin besar pula nilai deplesinya dan disebabkan oleh sistem pengelolaan yang kurang baik dan perubahan luas lahan akibat konversi lahan (3) Nilai kontribusi PDRB hijau sektor pertanian sub sektor tanaman pangan pada Kabupaten Banjar menunjukkan angka yang lebih kecil dibandingkan angka kontribusi PDRB konvensional dan sudah menunjukkan nilai aset modal alami berupa deplesi dan degradasi yang selama ini tidak diperhatikan dalam perhitungan PDRB konvensional (4) Kontribusi riil sektor pertanian sub sektor tanaman pangan di Kabupaten Banjar menunjukkan angka yang besar karena sudah dimasukkan perhitungan unsur lingkungan aset modal alami. Nilai kontribusi riil yang tinggi ini dapat menjadi cara meningkatkan pendapatan daerah dengan implikasi pelestarian lingkungan yang berkelanjutan.

\section{Saran}

Adapun saran yang dapat penulis berikan dari hasil penelitian ini diantaranya adalah (1) Bagi para peneliti selanjutnya diharapkan agar lebih mengembangkan dan menganalisis lebih dalam terkait kontribusi sektor pertanian khususnya subsektor tanaman pangan menggunakan pendekatan PDRB hijau. (2) Perhatian lebih terhadap lingkungan, khususnya sumber daya tanah di sektor pertanian. Upaya yang dapat dilakukan dengan intensifikasi lahan pertanian, pengendalian konversi lahan pertanian, serta perbaikan pemupukan menuju pemupukan berimbang. Tindakan lanjut dengan adanya lembaga yang mengawasi dan menangani degradasi tanah, serta peraturan yang mengatur mengenai alih fungsi lahan dari lahan pertanian menjadi lahan komersil. (3) Komitmen besar terhadap pemberdayaan lingkungan dengan peran pentingnya dalam memaksimalkan kesejahteraan daerah serta perencanaan pembangunan berkelanjutan (SDGs) di daerah. (4) Alokasi biaya lingkungan yang diambil mungkin bisa digunakan untuk mensejahterakan petani, memberi subsidi, dan fasilitas kepada petani. (5) Penggunaan perhitungan PDRB hijau sebagai perhitungan kontribusi kegiatan perekonomian yang di dalamnya sudah termasuk nilai dan jasa lingkungan.

\section{DAFTAR PUSTAKA}

Anshar, M. N., Zulfaridatul, S. M., \& Ahmad, Y. (2018). Contribution of The Foresty Sector to Regional Development of South Kalimantan Province (Green GRDP Calculation Approach), Ecoplan Vol. 1, No. 2, Oktober 2018.

Arifin, B. (2001). Spektrum Kebijakan Pertanian Indonesia. Jakarta: Erlangga.

Badan Pusat Statistik Kabupaten Banjar. (2019). Kabupaten Banjar dalam Angka 2019. Banjar:

Badan Pusat Statistik Kabupaten Banjar. (2018). Kabupaten Banjar dalam Angka 2018. Banjar:

Badan Pusat Statistik Kabupaten Banjar. (2017). Kabupaten Banjar dalam Angka 2017. Banjar:

Badan Pusat Statistik Kabupaten Banjar. (2016). Kabupaten Banjar dalam Angka 2016. Banjar:

Badan Pusat Statistik Provinsi Kalimantan Selatan. (2019). Provinsi Kalimantan Selatan dalam Angka 2019. Banjarbaru:

Badan Pusat Statistik Indonesia. (2019). Nilai Produksi dan Biaya Produksi per Musim Tanam per Hektar Budidaya Tanaman Padi Sawah, Padi Ladang, Jagung, dan Kedelai.

https://www.bps.go.id/statictable/2019/04 /10/2055/ nilai-produksi-dan-biayaproduksi-per-musim-tanam-per-hektarbudidaya-tanaman-padi-sawah-padiladang-jagung-dan-kedelai-2017.html

Badan Pusat Statistik Indonesia. (2019). Suku Bunga Kredit Rupiah Menurut Kelompok Bank, 2002-2019. https://www.bps.go.id/linkTableDinamis /view/id/1062

Deviane, A. (2017). Estimasi PDRB Hijau Jawa Barat. Bandung: Universitas Katolik Parahyangan. 
Emi, R. (2016). PDRB Hijau Sektor Kehutanan Melalui Pendekatan Nilai Ekonomi Jasa Lingkungan.

Hersaputri, L. D., \& Santoso, E. B. (2017). Estimasi Deplesi Lingkungan Subsektor Kehutanan di Jawa Timur, Jurbal Teknik ITS Vol. 6, No. 2, 2017, hal 2337-3520.

Keraf, S. A. (2010). Etika Lingkungan Hidup. Jakarta: Buku Kompas.

Mankiw, G. (2012). Pengantar Ekonomi Makro Edisi Asia. Jakarta Selatan: Salemba Empat.

Nurmala, T., \& Rodjak, A. (2012). Pengantar Ilmu Pertanian. Yogyakarta: Graha Utama.

Peraturan Pemerintah Nomor 46 Tahun 2017

Putra, W. (2013). Model Perhitungan Besaran PDRB Hijau Sektor Kehutanan di Kalimantan Barat melalui Pendekatan Jasa Lingkungan, Vol. 9, No. 1, Februari 2013, hal 49-68.

Ramdhani, G. (2018, Agustus 19). Kinerja Sektor Pertanian Wujud Implementasi Agenda Prioritas Nawacita. Retrieved from Liputan 6: https://www.liputan6.com/news/read/362 2660/kinerja-sektor-pertanian-wujudimplementasi-agenda-prioritas-nawacita
Ratnaningsih, M., \& Suparmoko, M. (2006). PDRB Hijau (Produk Domestik Regional Bruto Hijau). Jakarta: BPFE-Yogyakarta.

Setyarko, Y. (2008). Kontribusi Hijau Sektor Kehutanan pada PDRB dan Pembangunan Regional Kabupaten Batang Hari Provinsi Jambi, Jurnal Ekonomi Lingkungan Vol.12/No.2/2008.

Suparmoko, M. (1997). Ekonomi Sumberdaya Alam dan Lingkungan (Suatu Pendekatan Teoritis). Jakarta: BPFE-Yogyakarta.

Suparmoko, M. (2006). PDRB Hijau (Produk Domestik Regional Bruto Hijau): BPFE. Yogyakarta.

Suparmoko, M. (2008). Kontribusi Sektor Kehutanan Pada Pembangunan Daerah Kabupaten Blora, Jurnal Ekonomi Pembangunan Vol 13, No. 3, Desember 2008, hal 217-229.

Todaro, M. P., \& Smith, S. C. (2006). Pembangunan Ekonomi (Edisi Kesembilan). Jakarta: Penerbit Erlangga.

Undang-undang Nomor 32 Tahun 2019 Tentang Perlindungan dan Pengelolaan Lingkungan Hidup

Waluyati, L. R., \& dkk. (2010). Produk Domestik Regional Bruto (PDRB) Hijau Sektor Pertanian di Kabupaten Jayapura, Agro Ekonomi Vol. 17, No. 2, Desember 2010, hal 123-130. 